\title{
Experimental Porphyric Neuropathy: A Preliminary Report
}

\author{
ANDERS A.F. SIMA, JAMES C. KENNEDY, DENNIS BLAKESLEE and DAVID M. ROBERTSON
}

SUMMARY: An experimental model for the study of porphyric neuropathy is presented. Injection of either tetraphenylporphinesulfonate (TPPS), hematoporphyrin derivative $(H P D)$, or delta-aminolevulinic acid (ALA) into mice resulted in markedly decreased motor nerve conduction velocity (MNCV). The MNCV returned to normal within one week following the injection of large doses of $A L A$, and within three weeks following the injection of close to lethal doses of $H p D$. but there was no recovery of nerve function

RÉSUME: Nous présentons un modèle expérimental pour l'étude de la neuropathie porphyrique. L'injection chez la souris de Tetraphenyl-porphinesulfonate (TPPS). d'un dérivé de l'hématoporphyrine $(H p D)$. ou de lacide delta-aminolevilinique ( $A L A)$ produisit une réduction importante de la vitesse de conduction motrice nerveuse (MNCV). Le MNCV est retourné à la normale en desa d'une semaine suivant l'injection d'ALA, en deca de trois semaines suivant l'injection de doses presques léthales de $H p D$, mais il n'y eut within 60 days following injection of substantially smaller doses of TPPS. Ultrastructural examination of motor nerves at various times following TPPS injection revealed the gradual de velopment of structural abnormalities. Ultrastructional examination of the same nerves after a single dose of either $A L A$ or $H p D$ failed to demonstrate any abnormalities.

- The present observations call for precaution as to the use of TPPS as photosensitizer in human cancer treatment.

aucune récupération fonctionnelle de nerf dans les 60 jours suivant linjection de doses substantiellement plus faibles de TPPS. Lexamen ultrastructural des nerfs moteurs à divers moments après l'injection de TPPS montra le développement graduel d'anomalies structurales. Par contre le même examen après une dose unique d'ALA ou de HpD n'a pas montré d'anomalies.

Les observations présentes conduisent à la prudence dans l'emploi du TPPS dans le traitement du cancer chez l'humain.

\section{INTRODUCTION}

The acture intermittent (Swedish) form of hepatic porphyria is characterized by severe neurological abnormalities without obvious skin photosentivity, while both skin photosensitivity and neurological abnormalities may be observed in patients with porphyria variegata, the South African Caucasian form of hepatic porphyria. It has long been known that the skin photosensitivity results from abnormally high concentrations of porphyrins in the tissues and that photosensitivity can be reproduced experimentally by the administration of different types of porphyrins (MeyerBetz, 1913; Barker et al., 1970; Spikes, 1975). The mechanism underlying porphyric neuropathy, however, is less well understood. Acute intermittent porphyria is characterized by an increase in the excretion of the porphyrin precursors, delta-aminolevulinic acid (ALA) and porphobilinogen (PBG) without a corresponding increase in excretion of the porphyrins. Many investigators have therefore tested ALA and PBG for possible neurotoxicity (Goldberg et al., 1954; Goldberg and Rimington, 1954; Berlin et al.. 1954; Granick and Van den Schrieck, 1955; Jarrett et al., 1956; De Metteis, 1962; Biempica et al., 1967; Kosower and Rock, 1968; Feldman et al., 1968 and 1971; Marcus et al.. 1970; Becker et al.. 1971 and 1976; lsacsonet al., 1971; Shanley et al., 1972, 1975 and 1976; McGillion et al., 1973; Loots et al., 1975; Moore et al., 1976; Nicoll, 1976; Müller and Snyder, 1977; Dichter et al., 1977; Becker and Kramer, 1977; Bornstein et al., 1978; Cutler et al., 1978). Although there is good evidence that high concentrations of ALA may lead to changes in behavior, in cell membrane function, in neuromuscular and spinal transmission, there is no general agreement 
that ALA as such is directly responsible for porphyric neuropathy.

In this study mice were injected with single large doses of either tetraphenylporphinesulfonate (TPPS), hematoporphyrin derivative (HpD) or delta-aminolevulinic acid (ALA). We demonstrate in the present report for the first time decreased motor nerve conduction velocities after the injection of TPPS, HpD and ALA, as well as the development of structural changes in peripheral motor nerves after the injection of TPPS. Furthermore, the effects of these substances were investigated as to direct toxicity, persistence of photosensitivity and extrahepatic synthesis of porphyrins after ALA injection.

\section{MATERIALS AND METHODS \\ CHEMICALS}

TPPS. Tetraphenylporphinesulfonate tetrasodium salt was prepared according to the method of Busby et al (1975). The material was dialyzed until alkaline barium chloride solution failed to cause a precipitate.

$H p D$. Hematoporphyrin derivative was produced by a modification of the method reported by Dougherty et al (1970). Since $H p D$ preparations may vary greatly in purity and are relatively unstable, we have provided a detailed description of our method of preparation. Future reports will refer to this information.

Twelve grams of hematoporphyrin hydrochloride (Laboratoire Roussel, Paris, France) were added to $240 \mathrm{ml}$ of a mixture containing 19 volumes of glacial acetic acid and I volume of concentrated sulfuric acid. The reaction was allowed to proceed in the dark for 5 days at room temperature, with occasional stirring. The resulting solution was passed through a 0.2 polycarbonate filter and then divided equally a mong six 1 liter polyethylene centrifuge bottles. The bottles were immediately filled to the 1 liter mark with $3 \%$ sodium acetate in water, and the resulting red-brown precipitate pelleted by centrifugation $\left(4^{\circ} \mathrm{C}, 15 \mathrm{~min}\right.$ at $\left.2,500 \mathrm{~g}\right)$. The lightly colored supernatant was discarded and the sediment resuspended gently in 1 liter of cold water per centrifuge bottle. Following 3 such washes, the sediment was spread evenly about the walls of the centrifuge bottle and freeze-dried. The resulting powder was dissolved in $0.15 \mathrm{~N}$ $\mathrm{NaOH}$ (l g powder $/ 30 \mathrm{ml}$ of solution) and stirred in the dark for 1 hour at room temperature after which $0.15 \mathrm{~N} \mathrm{HCl}$ was added to reduce the $\mathrm{pH}$ to 7.2 . Then $0.15 \mathrm{~N}$ $\mathrm{NaCl}$ was added to bring the volume to 40 $\mathrm{ml}$, after which the solution (now $25 \mathrm{mg}$ $\mathrm{HpD} / \mathrm{ml}$ of $0.15 \mathrm{~N} \mathrm{NaCl}$ ) was sterilized by passage through 0.22 Millipore Millex units, dispensed into polystyrene tubes (Falcon Plastics, Oxnard, California) and stored at $-20^{\circ} \mathrm{C}$ until required.

It should be noted that all reagents were U.S.P. grade or better, and "sterile water for injection, U.S.P.", was used to make up all solutions. Equipment in contact with acidic solutions was rinsed with those same acids immediately before use; all other equipment was given a final rinse with glass-distilled water. No metal came in contact with any of the solutions or dry materials at any time during processing; all equipment and storage containers were made of either glass, teflon, polycarbonate, or polystyrene.

$A L A$. Delta-aminolevulinic acid hydrochloride, Sigma \#A-8879, was dissolved in isotonic saline. Solutions were neutralized with $0.15 \mathrm{~N} \mathrm{NaOH}$ before injection.

Bera-carotene was Eastman Kodak $\# 3702$. Since beta-carotene is insoluble in water, it was injected as a suspension in isotonic saline.

\section{ANIMALS}

Mice. DBA/2J mice from the Jackson Laboratory, Bar Harbor, Maine, and Swiss Albino mice from either BioBreeding Laboratories, Ottawa, Ontario, or Canadian Breeding Farms and Laboratories, Laprairie. Quebec, were matched for strain, sex and age in each experiment. All animals were injected at 10 weeks of age.

\section{MOTOR NERVE CONDUCTION VELOCITY (MNCV)}

MNCV was measured at various intervals following injection of either TPPS, $\mathrm{HpD}$ or ALA. Mice injected with saline alone served as controls.

TPPS was injected intraperitoneally (i.p.) in various doses (Fig. 2) in groups of 5 to $6 \mathrm{DBA} / 2 \mathrm{~J}$ mice. Close to lethal doses of $\mathrm{HpD}(100 \mathrm{mg} / \mathrm{kg})$ were injected i.p. into one group of $6 \mathrm{DBA} / 2 \mathrm{~J}$ mice (Fig. 4). HpD in doses of $80 \mathrm{mg} / \mathrm{kg}$ were injected i.p. in a group of 9 Swiss albino mice (Fig. 3). Finally a group of 10 Swiss albino mice were injected i.p. with $1000 \mathrm{mg} / \mathrm{kg}$ ALA (Fig. 3).

The animals were anesthetized with methoxyflurane and the MNCV was measured immediately. After measurements subcutaneous (flank) and intraperitoneal temperatures were taken by means of a 19 gauge needle thermocouples and a Bat- 8 digital microprobe thermometer (Bailey Instruments. Chicago. Illinois). The left sciatic nerve was stimulated at the sciatic notch and the tibial nerve posterior to the anke. Recordings were obtained from the muscle of the first interosseous space. Supramaximal stimuli $(6 \mathrm{~V})$ were generated at a frequency of $8 / \mathrm{sec}$ by a Grass SD stimulator. The action potentials of muscles were displayed on an oscilloscope and the latencies measured. Conduction velocity was calculated by dividing the distance between the two stimulation points by the difference between the two latencies.

\section{MORPHOLOGICAL STUDIES}

Groups of 5 control and 5 experimental DBA/2J mice injected with $150 \mathrm{mg}$ TPPS/kg body weight were sacrificed 5 , 30,60 and 120 days later. Groups of 5 control and 5 experimental Swiss albino mice were sacrificed 10 days after the injection of $80 \mathrm{mg} \mathrm{HpD} / \mathrm{kg}$ or $1000 \mathrm{mg}$ $\mathrm{ALA} / \mathrm{kg}$ body weight. The mice were anesthetized with methoxyflurane and then perfused with cacodylate-buffered paraformaldehyde-glutaraldehyde fixative through the left heart (Karnovsky, 1965). Specimens were taken from the right side (opposite to that on which nerve conduction velocity was measured) from the ventral root of the fifth lumbar segment, the sciatic and peroneal nerves. All nerves were postfixed in 1 per cent cacodylatebuffered osmium tetroxide, dehydrated and embedded in Epon. Grids were stained with uranyl acetate and lead citrate and examined under a Philips 400 electron microscope.

\section{EVALUATION OF DIRECT TOXICITY}

Mice were injected intravenously with various doses of either HpD or TPPS, according to Table $I$, and then held in subdued lighting for 7 days. Deaths were recorded daily.

\section{EVALUATION OF PERSISTENCE OF PORPHYRIN FOLLOWING INJECTION}

DBA/2J or Swiss albino mice were injected as above with various doses of TPPS, HpD or ALA, and then tested for photosensitivity at various times postinjection by exposure to Pyrex-filtered sunlight at an intensity of approximately $95 \mathrm{~mW} / \mathrm{cm}^{2}$. Scratching and rubbing of the ears, eyes, nose and tail during the immediately following exposure was considered to be evidence of a mild phototoxic reaction. More severe reactions resulted in obvious edema of the same sites. The most severe acute reaction was sudden death. Late effects including thickening and shortening of the ears and the development of hyperkeratotic lesions on the ears and tail. The mice were also examined for skin 
and serum fluorescence under longwave ultraviolet light at an intensity of 25 $\mathrm{mW} / \mathrm{cm}^{2}$.

\section{DEMONSTRATION OF EXTRAHEPATIC SYNTHESIS OF PORPHYRINS}

Swiss albino mice were injected intravenously, intraperitoneally or subcutaneously with $30 \mathrm{mg} \mathrm{ALA} / \mathrm{kg}$ of body weight, following which they were examined at regular intervals under longwave ultraviolet light at an intensity of 25 $\mathrm{mW} / \mathrm{cm}^{2}$. The development of the typical red fluorescence of porphyrins was taken as an indication that substantial amounts of porphyrin had been synthesized as a result of the injection of ALA.

\section{RESULTS}

\section{MOTOR NERVE CONDUCTION VELOCITY}

TPPS. Figure 2 summarizes the results. Mice injected with saline alone showed a relatively constant mean MNCV ranging from 51 to $55 \mathrm{~m} / \mathrm{sec}$ throughout the observation period. The muscle action potentials recorded from the interosseous muscle in TPPS injected mice showed increased latencies and decreased amplitudes (Fig. 1). Distal motor latencies were increased in proportion to the slowing of the MNCV (Fig. 1). The general shape of the action potentials did not differ between TPPS and control mice (Fig.
1). The motor nerve conduction velocity in TPPS injected mice showed a rapid decrease. Twenty four hours after the injection of $150 \mathrm{mg}$ TPPS $/ \mathrm{kg}$ body weight the MNCV was $32.2 \pm 1.1$ $\mathrm{m} / \mathrm{sec}$ as compared with $53.1 \pm 2.1$ in mice injected with saline. The MNCV in all TPPS injected mice was significantly decreased $(p<0.001) 24$ hours post injection (Fig. 2). Larger doses of TPPS resulted in a more severe decrease in MNCV than did lower doses (Fig. 2).

$H p D$. The injection of $100 \mathrm{mg}$ $\mathrm{HpD} / \mathrm{kg}$ body weight in DBA/2J mice resulted in a rapid decrease in $\mathrm{MNCV}$. The observed decrease to $36.7 \pm 3.2$ $\mathrm{m} / \mathrm{sec}$ within 20 hours of the injection was highly significant $(\mathrm{p}<0.001)$. At day 2 the MNCV was reduced to $60 \%$ of normal and remained so for approximately one week. Thereafter the MNCV showed a gradual recovery with values not significantly different from normal, 17 days after the injection (Fig. 4).

The injection of $80 \mathrm{mg} \mathrm{HpD} / \mathrm{kg}$ body weight in Swiss albino mice showed the same rapid decrease in MNCV. The recovery to normal values appeared faster. Hence, 7 days after the injection of $\mathrm{MNCV}$-values were not significantly different from those of control animals (Fig. 3).

TABLE I

\begin{tabular}{|c|c|c|}
\hline \multirow{2}{*}{$\begin{array}{l}\text { Dose injected intravenously } \\
\text { (mg/kg of body weight) }\end{array}$} & \multicolumn{2}{|c|}{ (a) Non-phototoxic deaths } \\
\hline & $\mathrm{HpD}$ & TPPS \\
\hline 75 & $0 / 8$ & - \\
\hline 100 & $0 / 8$ & - \\
\hline 125 & $2 / 8$ & - \\
\hline 150 & $6 / 8$ & $0 / 8$ \\
\hline 175 & $8 / 8$ & $0 / 8$ \\
\hline 200 & $8 / 8$ & $1 / 8$ \\
\hline 225 & $8 / 8$ & $0 / 8$ \\
\hline 250 & - & $1 / 8$ \\
\hline 275 & - & $1 / 8$ \\
\hline 300 & 一 & $3 / 8$ \\
\hline 400 & - & $8 / 8$ \\
\hline 700 & - & $8 / 8$ \\
\hline
\end{tabular}

(a) Mice held in subdued lighting for 7 days post-injection. All but two deaths occurred within 48 hours of injection. and all deaths occurred within 5 days.

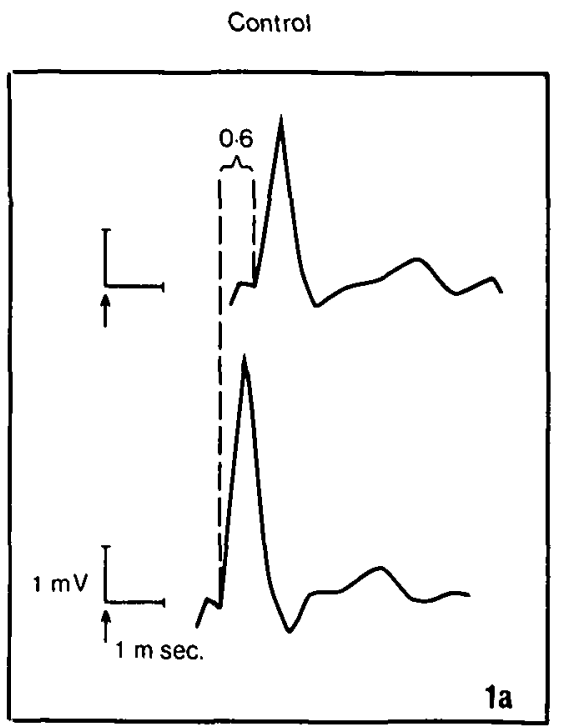

Figure la - Muscle action potentials in a control mouse recorded from the interosseous muscle of the foot. Stimulation at sciatic notch (top) and at the ankle (bottom). The distance between the stimulation points was $31 \mathrm{~mm}$ and the difference in latencies $0.6 \mathrm{msec}$. The calculated MNCV was $51.7 \mathrm{msec}$.

TPPS-mice

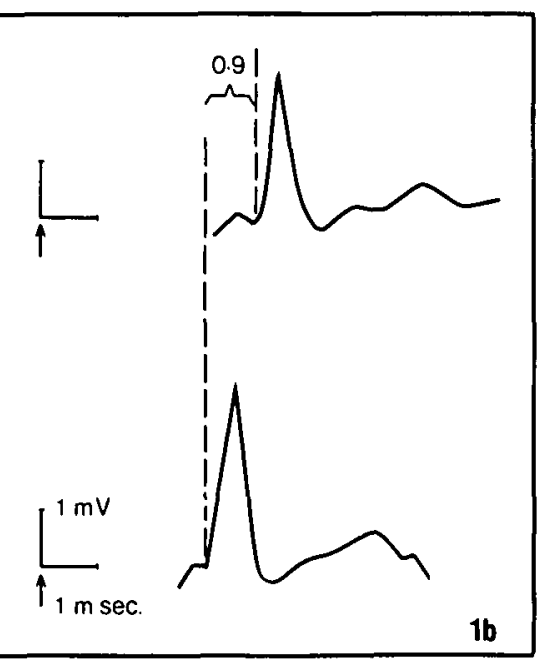

Figure $l b-$ Muscle action potentials in a TPPS-mouse 10 days after the injection of $150 \mathrm{mg}$ TPPS $/ \mathrm{kg}$. The distance between the two stimulation points was $29 \mathrm{~mm}$ and the difference in latencies 0.9 msec. The calculated MNCV was 32.2 msec. The amplitude in the TPPS mouse was $2.6 \mathrm{mV}$ as compared with 3.5 $\mathrm{mV}$ in the control mouse (Fig. la). 
MOTOR NERVE CONOUCTION VELOCITY (MNCV) IN TPPS TREATED MICE

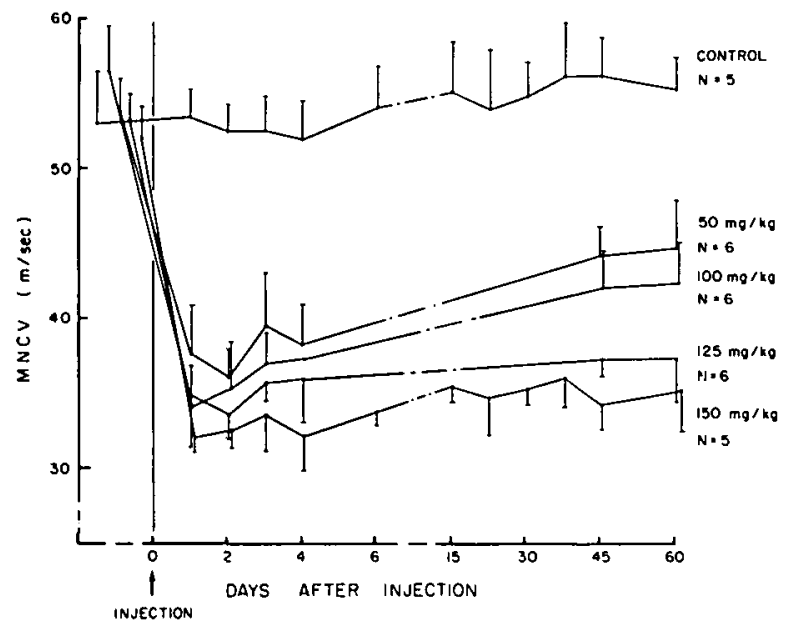

MOTOR NERVE CONDUCTION VELOCITY (MNCV) IN ALA AND HDD TREATED MICE

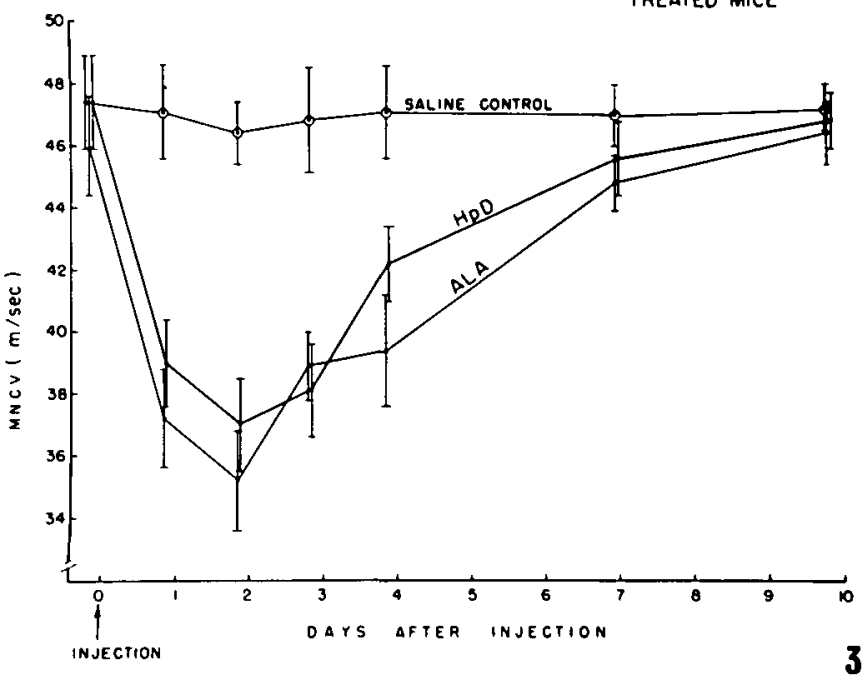

Figure 3 - Mice were injected intravenously with either saline or $\mathrm{HpD}(80 \mathrm{mg} / \mathrm{kg}$ of body weight), or int raperitoneally with ALA ( $1000 \mathrm{mg} / \mathrm{kg}$ of body weight), and then maintained for 10 days in subdued lighting. MNCV's were measured at intervals. Each point represents the mean $\pm 95 \%$ confidence limits of the 9 or 10 mice in each group.

Figure 2 - Mice were injected intraperitoneally with either saline
or various doses of TPPS, and then maintained for 60 days in subdued lighting. MNCV's (tibial nerve) were measured at intervals. Each point represents the mean MNCV \pm S.D. of the 5 or 6 mice in each group.

$A L A$. The intraperitoneal injection of $1000 \mathrm{mg} \mathrm{ALA} / \mathrm{kg}$ body weight into Swiss albino mice caused the same rapid decrease in $\mathrm{MNCV}$. Thus 20 hours after the injection the MNCV was $37.2 \pm 1.4 \mathrm{~m} / \mathrm{sec}$ and highly significant from normal $(p<0.001)$ (Fig. 3). The lowest values appeared on day 2 after which there was a relative rapid recovery to normal $\mathrm{MNCV}$ values 10 days after the injection (Fig. $3)$.

Monitored body temperature. The subcutaneous temperatures fluctuated as the mice recovered from anesthesia. The intraperitoneal temperatures remained stable. They did not differ between control animals and the various experimental groups. Accordingly TPPS injected mice (150 $\mathrm{mg} / \mathrm{kg}$ ) showed a temperature of 32.5 $\pm 1.2^{\circ} \mathrm{C} ; \mathrm{HpD}(80 \mathrm{mg} / \mathrm{kg}) 31.3 \pm$ $1.7^{\circ} \mathrm{C}$; ALA $34.4 \pm 1.4^{\circ} \mathrm{C}$ and saline (control) injected mice showed a temperature of $33.4 \pm 1.1$. It is therefore highly unlikely that the observed decreases in MNCV in experimental animals are due to temperature variations.

\section{MORPHOLOGICAL STUDIES}

The peroneal and sciatic nerves as well as the ventral root were examined ultrastructurally, at various intervals after the injection of $150 \mathrm{mg}$ TPPS $/ \mathrm{kg}$ body weight. No pathological changes were detectable 5 days post-injection.
The first demonstrable changes were observed 30 days after injection. They consisted of membranous profiles in the axons and the accumulation of floccular substance in the matrix of

MOTOR NERVE CONDUCTION VELOCITY (MNCV) IN HPD TREATED MICE

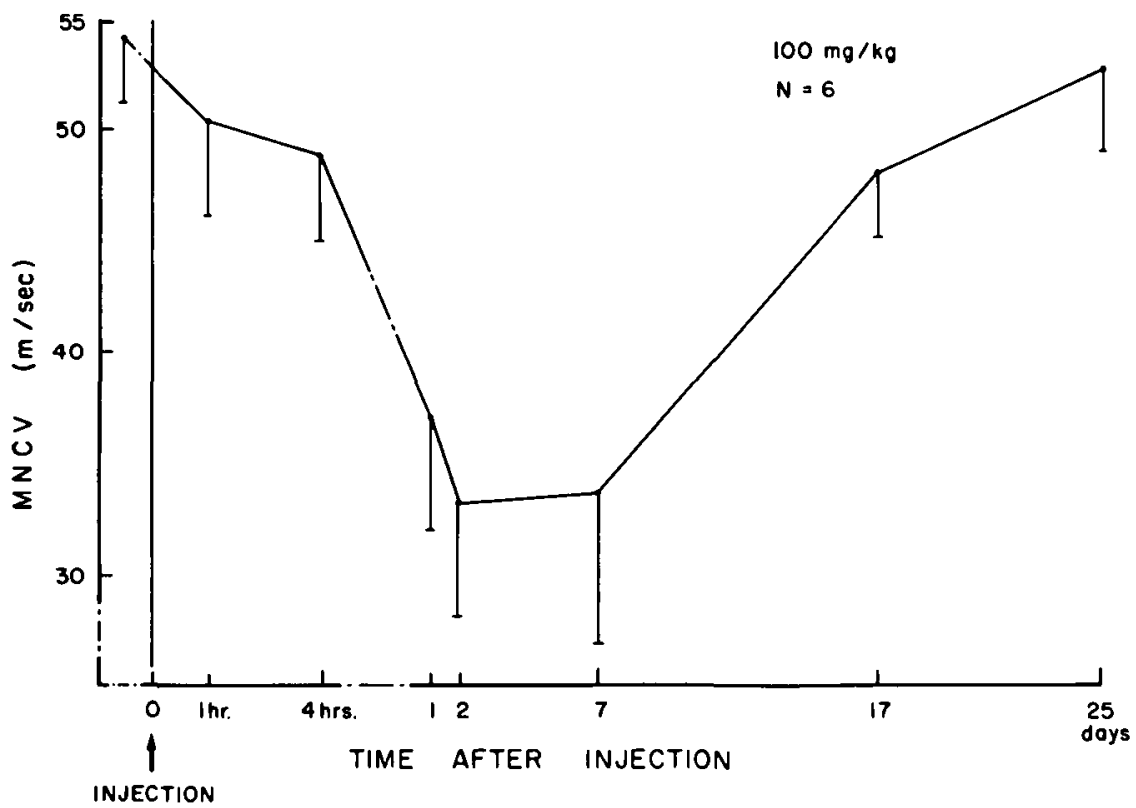

Figure 4 - Mice were injected intravenously with $100 \mathrm{mg} \mathrm{HpD} / \mathrm{kg}$ of body weight, and then maintained for 25 days in subdued lighting. MNCV's (tibial nerve) were measured at intervals. Each point represents the mean MNCV $\pm S$.D. of the 6 mice. 
axonal mitochondria. These structural alterations were found in localized areas within large axons and were more frequent in the peroneal and sciatic nerves than in the ventral root. Large myelinated fibers displayed extensive adaxonal Schwann cell ingrowths into the axoplasm partly enclosing organelle debris (Fig. 5).

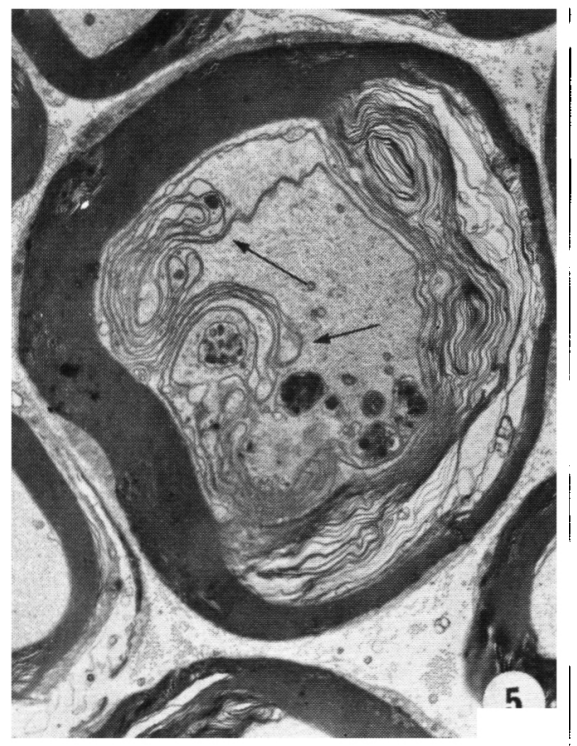

Figure 5 - Peroneal nerve 30 days after injection of $150 \mathrm{mg}$ TPPS $/ \mathrm{kg}$ body weight. Large myelinated fiber shows a complex array of adaxonal processes extending into the axoplasm (arrows). The axon contains organelle debris. $5325 x$.

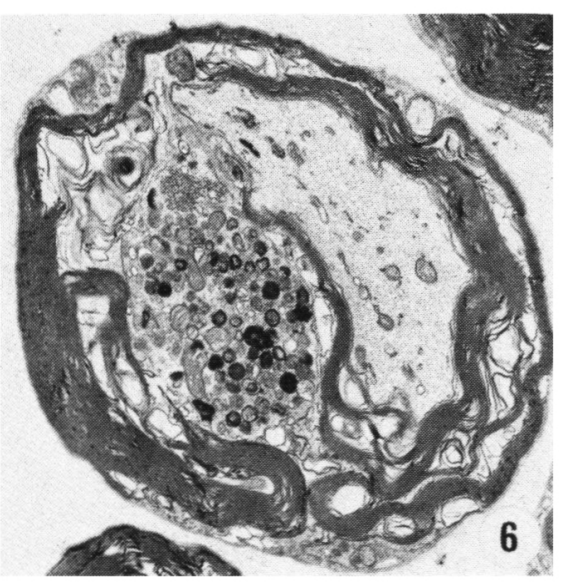

Figure 6 - Sciatic nerve 60 days after injection of $150 \mathrm{mg}$ TPPS $/ \mathrm{kg}$ body weight. The axon is intersepted and contains an abundance of organelle debris. The myelin sheath shows disruption and splitting of lamellae. $8280 \mathrm{x}$.
Sixty days post injection, large myelinated fibers particularly in the peroneal nerve showed extensive accumulations of membranous profiles, degenerated mitochondria and clear vesicles in the axon. The axons were often sequestered by the adaxonal Schwann cell cytoplasm (Fig. 6). Longitudinal sections showed accumulations of excessive neurofilaments in the paranodal regions. These neurofilaments were arranged in a swirling array and formed a juxtanodal cuff, leaving a central area containing neurotubules and mitochondria (Fig. 7). These axonal swellings appeared strictly localized to the juxtanodal areas and were sometimes large enough to override the adjacent paranodal area of the subsequent internode (Fig. 7). The myelin sheath surrounding the swellings showed attenuation and splitting. In this agegroup myelin vacuoles and so called bubbling of myelin were found along the entire internode (Fig. 8). Sequestration of axoplasm was frequently observed and consisted of adaxonal ridges engulfing and invaginating parts of the axoplasm giving rise to islets of axoplasm within the inner lip of the Schwann cell cytoplasm (Fig. 9). This mechanism of axonal sequestra-

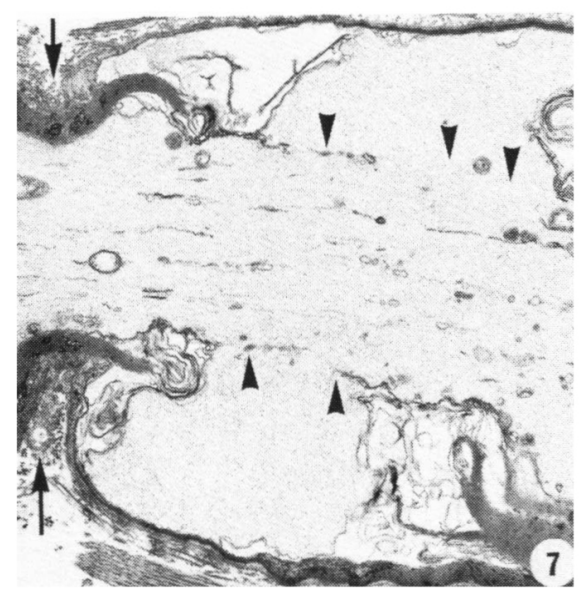

Figure 7 - Peroneal nerve 60 days after injection of $150 \mathrm{mg}$ TPPS $/ \mathrm{kg}$ body weight. Paranodal area showing juxtanodal axonal swelling due to the accumulation of neurofilaments. The axons show centrally located channel containing neurotubules and mitochondria (arrow-heads). Note distortion of the nodal gap due to the over-riding cuff of the swollen axon (arrows). $9200 \mathrm{x}$.

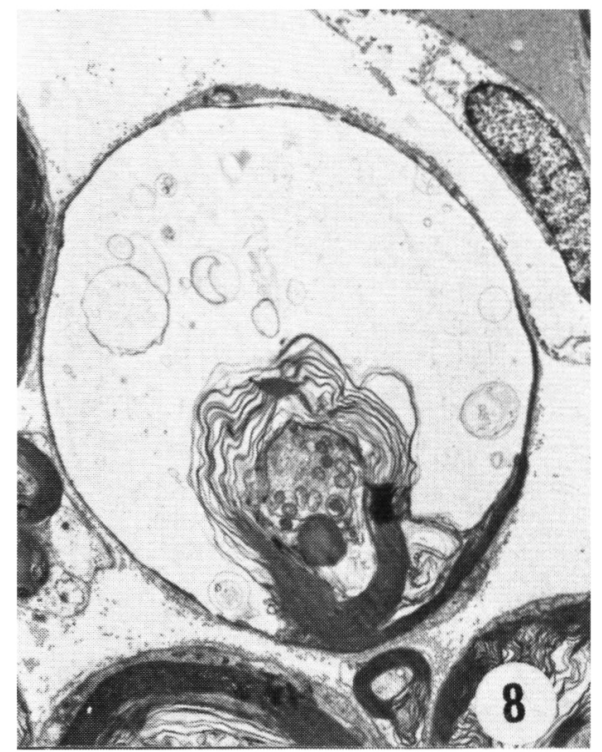

Figure 8 - Myelinated internode of the sciatic nerve 60 days after injection of $150 \mathrm{mg}$ TPPS $/ \mathrm{kg}$ body weight. Note atrophied axon containing altered mitochondria. The myelin sheath shows splitting and intramyelinic vacuoles. $5,980 \mathrm{x}$.

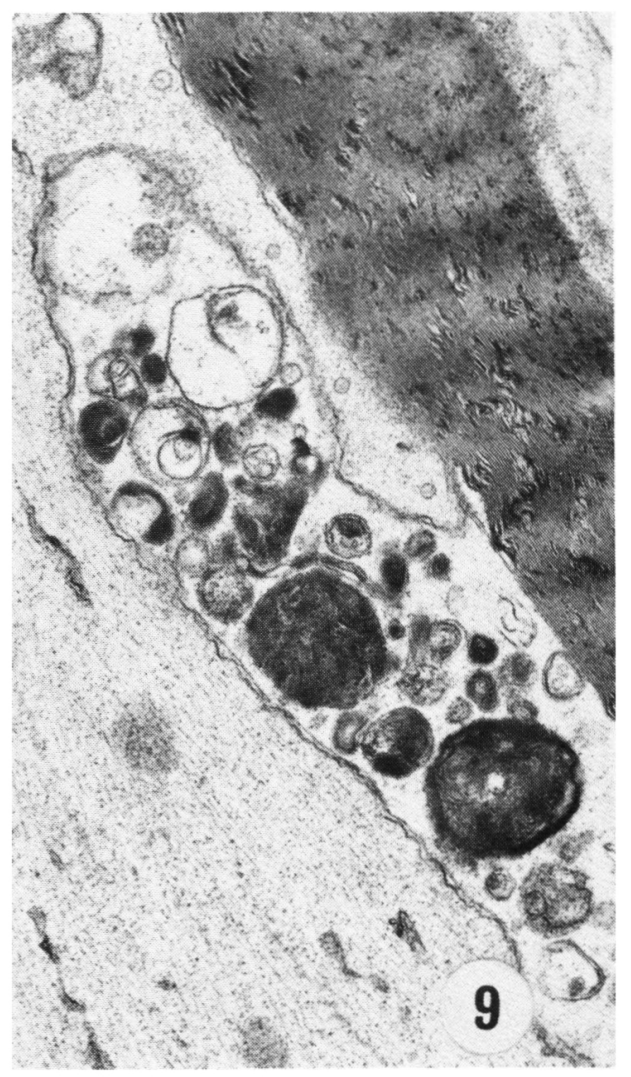

Figure 9 - Peroneal nerve 60 days after injection of $150 \mathrm{mg}$ TPPS/ $\mathrm{kg}$ body weight. Longitudinal section shows sequestered organelles in the inner lip of the Schwann cell. $16,000 \mathrm{x}$. 
tion was very occasionally found in control animals but was not nearly as frequent as in experimental animals. In the mice injected with TPPS 120 days previously the most striking lesion was marked shrinkage of axons surrounded by delaminated and desquamated myelin sheaths (Fig. 10). Regeneration and remyelination were not observed.

The described changes were most frequently found in the peroneal nerve (Fig. 11) and least frequently in the ventral root (Fig. 12), although they were qualitatively similar.

Examination of the same nerves ten days after a single dose of either $\mathrm{HpD}$ or ALA revealed no structural changes.

\section{DIRECT TOXICITY STUDIES}

Table 1 summarizes data from an experiment in which $\mathrm{DBA} / 2 \mathrm{~J}$ mice were injected intravenously with various doses of either TPPS or $\mathrm{HpD}$. It is apparent that $\mathrm{HpD}$ is more toxic than TPPS, on a per $\mathrm{mg}$ basis. However, since the dodecahydrated sodium salt of TPPS has a molecular weight almost double that of $\mathrm{HpD}$, the toxicities of the two porphyrins on a molar basis were not strikingly different. It was noted that the mice began to die only when the doses of porphyrin became large enough to overload the porphyrin-binding capacity of the plasma proteins. As might be expected if serum-bound porphyrin is relatively non-toxic, we found that the toxicity of intraperitoneal injections of $\mathrm{HpD}$ was greater than that of intravenous injections, and that this toxicity could be reduced significantly by adding serum albumin to $\mathrm{HpD}$ prior to injection.

No deaths resulted from intraperitoneal injections of ALA at doses up to $1000 \mathrm{mg} / \mathrm{kg}$ of body weight.

\section{PERSISTENCE OF POR PHYRIN FOLLOWING INJECTION}

Intraperitoneal injections of 1000 mg ALA/ $/ \mathrm{kg}$ of body weight into Swiss albino mice caused skin fluorescence and a mild skin photosensitivity which were first detectable approximately 1 hour post-injection and lasted for less than 2 days. Intravenous injections of $100 \mathrm{mg} \mathrm{HpD} / \mathrm{kg}$ of body weight caused skin fluorescence and skin photosensitivity which began immediately post-injection and could be detected for approximately 5 weeks. After smaller doses the fluorescence was weaker and lasted for an appropriately shorter time. Swiss albino mice injected intraperitoneally with $150 \mathrm{mg}$ TPPS $/ \mathrm{kg}$ of body weight 51 days prior to testing were killed within 20 minutes by whole-body exposure to Pyrex-filtered sunlight. After 86 days, exposure to sunlight for only 5 minutes was sufficient to cause non-lethal phototoxic reactions. Even after 107 days the mice still developed swollen ears, tails and faces after a 30 minute exposure, and the serum still showed fluorescence. The intraperitoneal injection of $500 \mathrm{mg}$ of beta-carotene per $\mathrm{kg}$ of body weight 5 hours prior to exposure to the filtered sunlight resulted in a substantial degree of protection against the phototoxic reactions.

In DBA/2J mice, definite serum fluorescence persisted for at least 96 days in mice given as little as $50 \mathrm{mg}$ of TPPS/ kg of body weight. Phototoxic damage in the $\mathrm{DBA} / 2 \mathrm{~J}$ mice was limited to the ears, the periorbital tissues, the nose, and the tail, since the dark fur protected the rest of the body from exposure. The severity of phototoxic damage was directly proportional to the amount of TPPS injected.

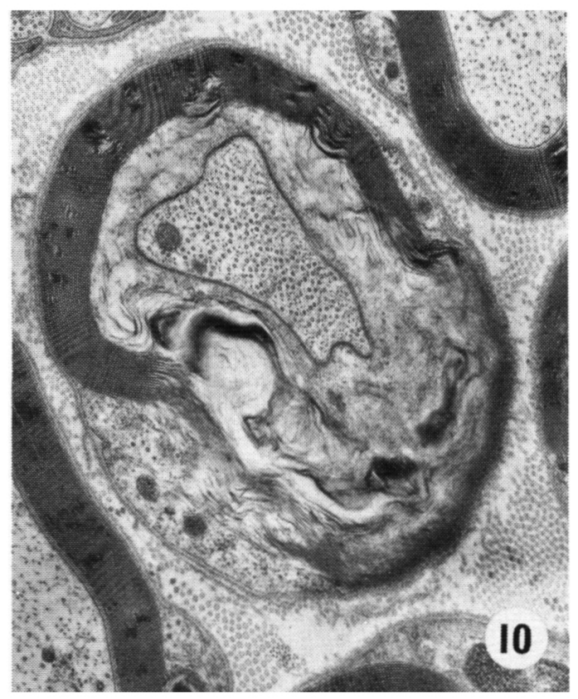

Figure 10 - Ventral root 120 days after the injection of $150 \mathrm{mg}$ TPPS $/ \mathrm{kg}$ body weight. Myelinated fiber showing marked axonal atrophy. The redundant myelin sheath shows delamination. $21,450 \mathrm{x}$.
Microscopic examination of the ears showed extensive fibroblast proliferation in the dermis with a diffuse mononuclear inflammatory reaction and prominent vascular proliferation. The

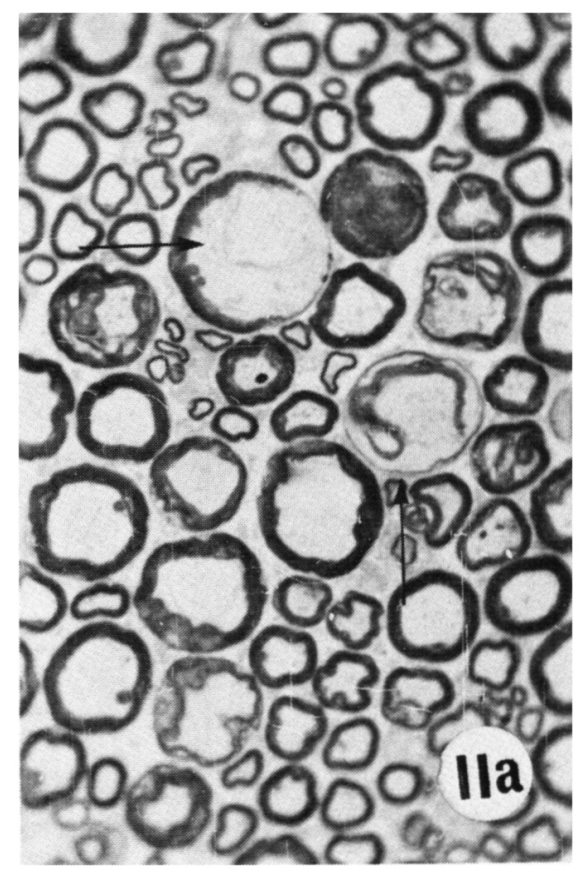

Figure $1 / a-$ Peroneal nerve 60 days after the injection of $150 \mathrm{mg}$ TPPS $/ \mathrm{kg}$ body weight. Large myelinated fibers show axonal swellings with attenuated myelin sheath (arrows). $1408 \mathrm{x}$.

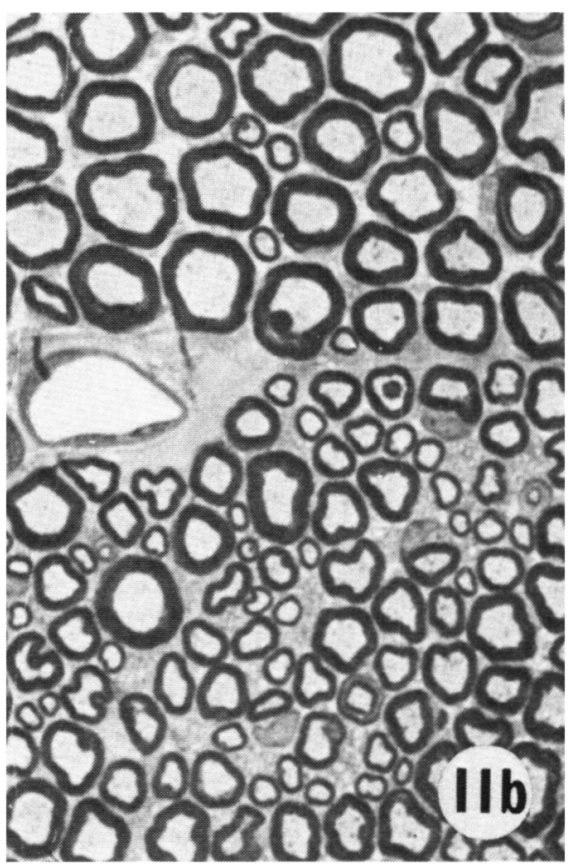

Figure $l l b$ - Peroneal nerve of agematched control mouse. $1408 \mathrm{x}$. 
epidermis showed focal separation from dermis at the basement membrane, so called bullae.

\section{EXTRAHEPATIC SYNTHESIS OF PORPHYRINS}

None of the mice injected either intravenously or intraperitoneally with

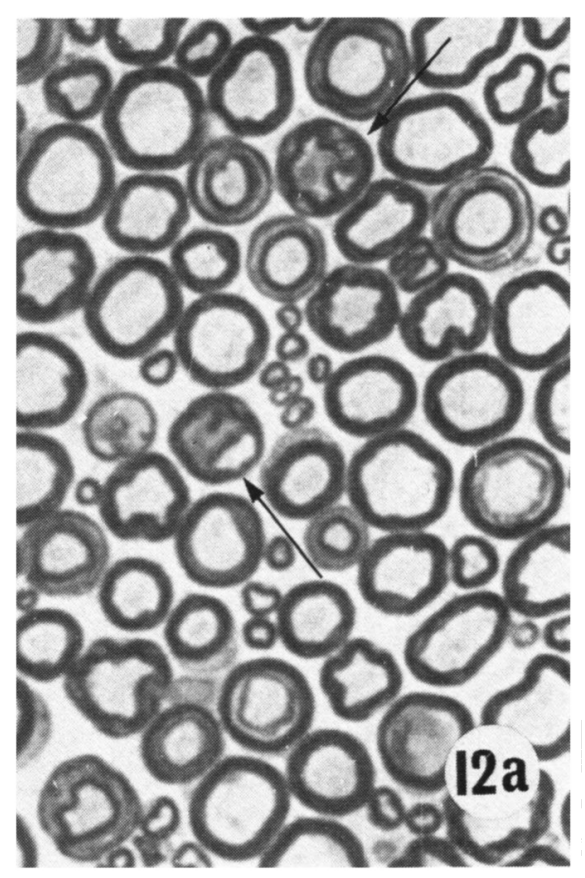

Figure $12 a-$ Ventral root 120 days after the injection of $150 \mathrm{mg}$ TPPS $/ \mathrm{kg}$ body weight. A few large myelinated fibers show axonal atrophy (arrows). $1408 \mathrm{x}$.

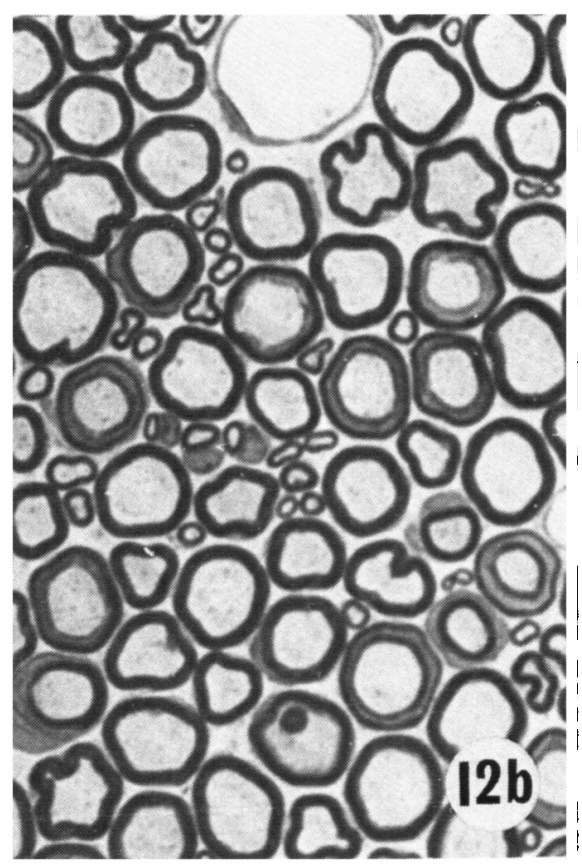

Figure $12 b-$ Ventral root of age-matched control mouse. $1408 \mathrm{x}$.
$30 \mathrm{mg}$ ALA $/ \mathrm{kg}$ of body weight developed any detectable skin fluorescence. However, those mice which had been given a subcutaneous injection localized to either the anterior third or posterior half of the tail showed the typical red fluorescence of porphyrin at the injection site, but nowhere else. The fluorescence was well-developed within 2 hours of the injection, and lasted for slightly less than 24 hours. Control mice given comparable amounts of citric acid as localized subcutaneous injections did not develop detectable fluorescence at the injection sites.

\section{DISCUSSION}

The injection into mice of a single large dose of ALA (1000 $\mathrm{mg} / \mathrm{kg})$ resulted in photosensitivity and skin fluorescence which lasted approximately 1 day, and a rapid decrease in MNCV lasting approximately one week before it recovered to normal values. No structural changes could be demonstrated in the peripheral nerves after this injection. The injection of a single large dose of $\mathrm{HpD}(100 \mathrm{mg} / \mathrm{kg})$ resulted in photosensitivity and skin fluorescence which lasted approximately 5 weeks, and a rapid decrease in MNCV which lasted less than 3 weeks before recovering to normal values. Structural changes of peripheral nerves failed to develop after a single injection of $\mathrm{HpD}$. The injection of a single large dose of TTPS ( $150 \mathrm{mg} / \mathrm{kg}$ ) resulted in photosensitivity and skin fluorescence which lasted more than 3 months, serum fluorescence that persisted for even longer, a rapid decrease in MNCV which appeared to be irreversible. First one month after the injection the gradual development of morphological abnormalities in the peripheral nerves could be demonstrated. These results strongly suggest that ALA, HpD and TPPS are capable of inducing a metabolic disturbance in peripheral motor nerves resulting in impaired propagation of the electrical impulse. Since the decreased MNCV recovered to normal after the injection of single doses of ALA or HpD, and since no structural abnormalities developed after these injections, it can be assumed that the metabolic derangement was reversible as the substances cleared from the circula- tion and tissues. TPPS on the other hand persisted in the circulation for a considerably longer time allowing it not only to cause an irreversibly decreased MNCV but also later occurring structural changes.

The slowing of the nerve conduction velocity in these experiments was accompanied by decreased amplitude of the action potential. The decreased MNCV is most likely the result of a conduction block of large myelinated fibers.

In TPPS-mice the earliest pathological changes were found in axonal mitochondria one month post-injection. These changes were followed by axonal sequestration and paranodal accumulation of deranged neurofilaments, an indication of impaired axonal transport. Changes also occurred in the myelin sheath, such as vacuolization and myelin bubbling, which appeared to be independent of the axonal pathology. Later changes were characterized by axonal atrophy accompanied by secondary myelin breakdown. These changes involved mainly large myelinated fibers and showed a clear gradient of severity with the most severe changes in the peroneal nerve and least severe in the ventral root. Both the qualitative and the quantitative changes were consistent with a dying back phenomenon. A similar sequence of events has been demonstrated in hexacarbon neuropathies (Spencer and Schaumburg, 1976; Sabri et al., 1979), and in different experimental models of diabetes mellitus (Sima and Robertson, 1979, Sima, 1980). Certain other changes such as vacuolization of the myelin sheath are similar to changes characteristic of lead neuropathy (Lampert and Schochet, 1968).

Comparable electrophysiological and morphological changes have been reported in humans with acute intermittent porphyria. Flügel and Druschky (1977) measured various electrophysiological parameters in such patients and concluded that the severity of the decrease in MNCV in the tibial nerve was directly related to the severity of the disease, and that it showed the characteristics of a primary axonopathy rather than that of primary demyelination. Recent morphological studies support this con- 
clusion (Cavanagh and Mellick, 1965; Kaeser, 1965; Cavanagh and Ridley, 1967), although there certainly have been studies which support a mechanism of primary segmental demyelination (Denny-Brown and Sciarra, 1945; Gibson and Goldberg, 1956) and others which indicate that both mechanisms may be operative (Anzil and Dozic, 1978). Wochnik-Dyjas et al (1978) presented data indicating that a decrease in MNCV was present in some patients following acute attacks associated with clinical evidence of motor polyneuropathy, and that both the electrophysiological and the clinical abnormalities were sometimes transient, the measurements returning to normal some time after the termination of the acute attack. They concluded that the neurological abnormalities caused by porphyria are strictly functional at first, but that prolonged or repeated acute attacks can lead to permanent damage in the form of axonal degeneration. This is in keeping with the results of the present experimental model.

Although we can reproduce in mice both functional and morphological changes similar to those observed in humans who develop porphyric neuropathy, this by itself does not prove that our animal model accurately reproduces the pathogenesis of porphyric neuropathy at the biochemical level. The biochemical basis for porphyric neuropathy is not well understood at present. However, since porphyric neuropathy is commonly found in association with acute intermittent porphyria, in which the concentration of porphyrins in the circulation is not usually elevated, it has generally been assumed that porphyrins as such could not be responsible for the neuropathy. Consequently, suspicion has been directed primarily at the porphyrin precursors ALA and PBG, abnormally large amounts of which are synthesized by the liver and released into the circulation.

It has been demonstrated in organotypic tissue culture (Whetsell et al, 1978) that porphyrins can be synthesized from ALA by both Schwann cells and neurons. This is not surprising since all cells that contain the biochemical machinery necessary for synthe- sizing heme-containing enzymes might be expected to produce porphyrins from ALA. Extrahepatic synthesis of porphyrins was also demonstrated in the present study.

In the present experimental design the question arises however, how ALA and porphyrins get access to the peripheral nerves. Two possibilities are plausible. It would be possible that the substances may pass the bloodnerve-barrier and thereby get access to the endoneurium. However, it is known that ALA and probably porphyrins do not cross the bloodbrain-barrier (McGillion et al, 1973; Shanley et al, 1975). It may also be possible that the substances are taken up at unprotected sites of the peripheral nerves such as the motor end plates. They would then be transported in a retrograde fashion in the same way as certain viruses, toxins and other macromolecules gain access to the nervous system (Ryser, 1970; Habermann, 1977). These possibilities are at the present time being investigated (Sima)

The effect of ALA, HpD and TPPS on the peripheral nerve metabolism is not known and can only be speculated upon. It has been suggested by Labbe (1967) that porphyrins may inhibit the incorporation of structural proteins into mitochondrial membrane and thus cause interference with mitochondrial function. On the other hand, the possibility exists that $\mathrm{HpD}$ and TPPS may exert a feed back inhibition of $\delta$-ALA-dehydrase (cf Bacchus, 1976) and thereby indirectly elevate the ALA concentration.

Delta-ALA is known as a potent $\left(\mathrm{Na}^{+} \mathrm{K}^{+}\right.$)-ATP-ase inhibitor (Becker et al, 1971; Niklowitz, 1977). It may therefore very well impoverish the membranous ion handling and prevent the transmission of the electric impulse. In this context it is interesting to note that one of the underlying mechanisms of lead neuropathy is thought to be the same, since lead also inhibits $\delta$-ALAdehydrase (Bacchus, 1976). In the present study structural changes of the myelin were demonstrated that are similar to those of lead neuropathy (Lampert and Schochet, 1968).

We therefore suggest as a working hypothesis, until further knowledge has been gathered, that both ALA and porphyrins should be considered as inducers of the abnormalities of nerve function and morphology in porphyric neuropathy.

In summary the present study has demonstrated for the first time functional abnormalities of motor peripheral nerves in mice after the injection of ALA, HpD and TPPS. In addition TPPS caused later occurring structural peripheral nerve changes indicative of an axonal neuropathy of dying back type, not dissimilar from human porphyric neuropathy.

The present models may therefore be useful experimental tools for the study of porphyric neuropathy and will permit detailed neurophysiological, biochemical, structural and morphometric studies to be carried out in a sequential fashion.

However, this work has significance in another area also. Photoradiation therapy for cancer is an experimental form of therapy which appears to have substantial advantages over conventional radiation therapy in certain clinical situations. Most of the clinical trials which are in progress at present make use of $\mathrm{HpD}$ for semi-selective photosensitization of the malignant tissue (Kelly and Snell, 1976; Dougherty et al., 1978; Kennedy, 1979), but the replacement of $\mathrm{HpD}$ by TPPS has been strongly advocated (Tsutsui et al., 1975) since a substantial amount of work in experimental animals and in vitro indicates that TPPS is clearly superior to $\mathrm{HpD}$ in some important respects (Winkelman, 1962 and 1967; Winkelman and Hayes, 1963; Winkelman et al., 1967). However, our finding that TPPS can persist in the circulation of mice for months following a single injection and can lead to a persistent decrease in $\mathrm{MNCV}$ and the gradual development of structural changes in peripheral nerves is a warning that TPPS could be a dangerous substitute for $\mathrm{HpD}$. We therefore strongly urge that electrophysiological and morphological studies of peripheral nerves be included in the preclinical evaluation of any other natural or synthetic porphyrin which may be considered for use as a sensitizer in photoradiation therapy for cancer. 


\section{ACKNOWLEDGEMENTS}

The assistance of Dr. L. Kerur with the MNCV measurements and the technical skills of Mrs. Kazy Hay are gratefully acknowledged. We wish also to thank Dr. G.S. Marks for his stimulating and informative discussions.

Supported by Grants MA-5857 and MA-7117 from the Medical Research Council of Canada, Grant No. 352 from the Ontario Cancer Treatment and Research Foundation. and a grant from the National Cancer Institute of Canada

\section{REFERENCES}

ANZIL, A.P., DOZIC S.: (1978) Peripheral nerve changes in porphyric neuropathy. Findings in a sural nerve biopsy. Acta Neuropathol. 42, 121-126.

BACCHUS, H.: (1976) Essentials of metabolic diseases and endocrinology. pp. 235-253. University Park Press, Baltimore.

BARKER, D.S., HENDERSON, R.W., STOREY, E. (1970) The in vivo localization of porphyrins. Br. J. Exp. Pathol. 51, 628-638.

BECKER, D.M., VILJOEN, J.D., KRAMER, S.: (1971) The inhibition of red cell and brain ATPase by delta-aminolaevulinic acid. Biochim. Biophys. Acta 225, 26-34.

BECKER, D.M., VILJOEN, J.D., KRAMER, $S$ : (1976) Porphyrin precursors and their effects in vitro on some aspects of nerve function. In: Porphyrins in human diseases (ed. M. Doss), pp. 163-172. Basel; Karger.

BECKER, D.M., KRAMER, S.: (1977) The neurological manifestations of porphyria: a review. Medicine 56, 411-423.

BERLIN, N.I., GRAY, C.H.. NEUBERGER, A.. SCOTT, J.J.: (1954) The metabolism of the porphyrin precursor, delta-aminolaevulinic acid, in normal man and in the rat. Biochem. J. 58, XXX

BIEMPICA. L., KOSOWER, N., NOVIKOFF, A.: (1967) Cytochemical and ult rastructural changes in rat liver in experimental porphyria. Lab. Invest. 17, 171-189.

BORNSTEIN, J.C., PICKETT, J.B., DIAMOND, I.: (1978) Inhibition of the evoked release of acetylcholine by the porphyrin precursor delta-aminolevulinic acid. Ann. Neurol. 5, 94-96.

BUSBY, C.A., DINELLO, R.K., DOLPHIN, D.: (1975) A convenient preparation of meso-tetra (4-sulfonatophenyl) porphyrin. Can. J. Chem. 53, 1554-1555.

CAVANAGH. J.B., MELLICK, R.A.: (1965) On the nature of the peripheral nerve lesions associated with acute intermittent porphyria. J. Neurol. Neurosurg. Psychiat. 28, 320-327.

CAVANAGH, J.B., RIDLEY, A.R.: (1967) The nature of the neuropathy complicating acute intermittent porphyria. Lancet $i i, 1023-1024$.

CUTLER, M.G., DICK, J.M., MOORE, M.K.: (1978) Effect of delta-aminolevulinic acid on frog nerve-muscle function. Life Sci. 23. 2233-2238.

DE METTEIS, F.: (1962) Les maladies du métabolisme des porphyrines. 2e Coll. Int. de Biologie, Saclay.

DENNY-BROWN, D., SCIARRA, D.: (1945) Changes in the nervous system in acute porphyria. Brain $68,1-16$.

DICHTER, H.N., TADDEINI, L., LIN, S.,
AYALA, G.F.: (1977) Delta-aminolevulinic acid. Effect of a porphyrin precursor on an isolated neuronal preparation. Brain Res. 126. 189-195.

DOUGHERTY, T.J., KAUFMAN, J.E., GOLDFARB, A., WEISHAUPT, K.R., BOYLE, D., MITTLEMAN, A.: (1978) Photoradiation therapy for the treatment of malignant tumors. Cancer Res. 38, 26282635

FELDMAN, D.S.. LEVERE, R.D., LIEBERMAN, J.S.: (1968) Presynaptic neuromuscular inhibition by delta-aminolevulinic acid, a porphyrin precursor. Trans. Am. Neurol. Assoc. 93. 206-208.

FELDMAN, D.S., LEVERE, R.D., LIEBERMAN. J.S. CARDINAL. R.A.. WATSON. C.J.: (1971) Presynaptic neuromuscular inhibition of porphobilinogen and porphobilin. Proc. Natl. Acad. Sci. USA 68, 383386.

FLUGEL. K.A.. DRUSCHKY. K-F.: (1977) Electromyogram and nerve conduction in patients with acute intermittent porphyria. J. Neurol, 2/4, 267-279.

GIBSON, J.B., GOLDBERG, A.: (1956) The neuropathology of acute porphyria. J. Pathol. Bacteriol. 71, 495-509.

GOLDBERG, A., PATON, W.D.M.. THOMPSON, J.W.: (1954) Pharmacology of the porphyrins and porphobilinogen. Br. J. Pharmacol. Chemther. 9, 90-94.

GOLDBERG, A.. RIMINGTON, C.: (1954) Fate of porphobilinogen in the rat. Relation to acute porphyria in man. Lancet ii, 172173.

GRANICK, S., VAN DEN SCHRIECK, H.G.: (1955) Porphobilinogen and delta-aminolevulinic acid in acute porphyria. Proc. Soc. Exp. Biol. 88, 270-273.

HABERMANN, E.: (1977) Transmembranal and intracellular transport of pharmacologically active proteins and polypeptides. Naunyn-Schmiedeberg's Arch. exp. Path. Pharmak. 297. 11-14

ISAACSON, L.D., DOUGHLAS, R., EALES, L.: (1971) Inhibition of sodium and water transport by delta-aminolaevulinic acid (ALA). S. Afro. J. Lab. Clin. Med. 17, 97-99.

JARRETT, A.. RIMINGTON, C., WILLOUGHBY, D.A.: (1956) Delta-aminolaevulinic acid and porphyria. Lancet $i, 125$ 127.

KAESER, H.E.: (1965) Veränderungen der Leitgeschwindigkeit bei Neuropathien und Neuritiden. Fortschr. Neurol. Psychiat. 33, 222-248.

KARNOVSKY, M.J.: (1965) A formaldehyde glutaraldehyde fixative of high osmolarity for use in electron microscopy. J. Cell Biol. 27, 137A.

KELLY, J.F., SNELL, M.E.: (1976) Hematoporphyrin derivative: a possible aid in the diagnosis and therapy of carcinoma of the bladder. J. Urol. 115, 150-151.

KENNEDY, J.C.: (1979) Hematoporphyrin photoradiation therapy: a useful alternative to ionizing radiation for the local control of cancer. Proc. Can. Assoc. Radiol. 42nd Annual Meeting, (Abstract, page 213)
KOSOWER, N.S., ROCK, R.A.: (1968) Seizures in experimental porphyria. Nature (Lond) 217. 565-567.

LABBE, R.F.: (1967) Metabolic anomalies in porphyria. The result of impaired biological oxidation? Lancet $i, 1361-1364$.

LAMPERT, P.W.. SCHOCHET, S.S.: (1968) Demyelination and remyelination in lead neuropathy. Electron microscopic studies. J. Neuropath. Exp. Neurol. 27. 527-545.

LOOTS, J.M., BECKER, D.M., MEYER, B.J. GOLDSTUCK, N., KRAMER. S.: (1975) The effect of porphyrin precursors on monosynaptic reflex activity in the isolated hemisected frog spinal cord. J. Neurol. Trans. 36, 71-81.

MARCUS, R.J., WETTERBERG, L... YUWILER, A., WINTERS, W.D.: (1970) Electroencephalographic and behavioral effects of experimental porphyria in the rat. Electroenceph. Clin. Neurophysiol. 29, 602-607.

MCGILLION, F.B., MOORE, M.R.. GOLDBERG, A..: (1973) The effect of deltaaminolaevulinic acid on the spontaneous activity of mice. Scott Med. J. 18, 133.

MEYER-BETZ. F.: (1913) Untersuchungen über die biologische (photodynamische) Wirkung des Hämatoporphyrins und anderer Derivate des Blut-und Gallenfarbstoffs. Deutsches Arch. Klin. Med. //2, 476503.

MOORE, M.R., McGILI.ION, F.B., GOLDBERG、A.: (1976) Some pharmacological and behavioural effects of delta-aminolaevulinic acid. In: Porphyrins in human diseases (ed. M. Doss), pp. 148-154. Basel: Karger.

MÜLLER. W.E.. SNYDER. S.H.: (1977) Delta-aminolevulinic acid: Influences on synaptic GABA receptor binding may explain CNS symptoms of porphyria. Ann. Neurol. 2. 340-342.

NICOLL. R.A.: (1976) The interaction of porphyrin precursors with GABA receptor in the isolated frog spinal cord. Life Sci. 19 $521-525$.

NIKLOWITZ, W.J.: (1977) Subcellular mechanisms in lead toxicity: significance in childhood encephalopathy, neurological sequelae, and late dementias. In: Neurotoxicology, Vol. I Ed. L. Roizin. H. Shiraki and N. Grcevic. Raven Press, New York, pp. 289298.

RYSER, H.J.P.: (1970) Transport of macromolecules, especially proteins into mammalian cell. Proc. IVth Int. Congr. Pharm., Vol. 3. Schwabe, Basel. pp. 96-132.

SABRI. M.I., MOORE, C.L...SPENCER, P.S. (1979) Studies on the biochemical basis of distal axonopathies. I. Inhibition of glycolysis by neurotoxic hexacarbon compounds. J. Neurochem. 32. 683-689.

SHANLEY, B.C., TALJAARD, J.J.F., DEPPE. W.M., JOUBERT. S.M.: (1972) Deltaaminolaevulinic acid in acute porphyria. $S$. Afr. Med. J. 46, 84.

SHANLEY, B.C., NEETHLING, A.C., PERCY, V.A.. CARSTENS. M.: (1975) Neurochemical aspects of porphyria. Studies on the possible neurotoxicity of delta-amino- 
laevulinic acid. S. Afr. Med. J. 49, 576-580.

SHANLEY, B.C., PERCY, V.A., NEETHLING, A.C.: (1976) Neurochemistry of acute porphyria. Experimental studies on deltaaminolaevulinic acid and porphobilinogen. In: Porphyrins in human diseases (ed. M. Doss), pp. 155-162. Basel: Karger.

SIMA. A.A.F., ROBERTSON, D.M.: (1979) Peripheral neuropathy in the diabetic mutant mouse. An ultrastructural study. Lab. Invest. 40, 627-632.

SIMA, A.A.F.: (1980) Peripheral neuropathy in the spontaneously diabetic BBW-rat. An ultrastructural study. Acta Neuropath. (Berl.) 51, 223-227.

SPENCER, P.S., SCHAUMBERG, H.H.: (1976) Central-peripheral distal axonopathy - the pathology of dying-back polyneuropathies. In: Progress in Neuropathology. Volume III (ed. H.M. Zimmerman), pp. 253-
295. New York and London: Grune and Stratton.

SPIKES, J.D.: (1975) Porphyrins and related compounds as photodynamic sensitizers. Ann. NY Acad. Sci. 244, 496-508.

TSUTSUI, M. CARRANO, C., TSUTSUI, E.A.: (1975) Tumor localizers: porphyrins and related compounds (unusual metalloporphyrins XXIII). Ann. NY Acad. Sci. 244. 674-684.

WHETSELL, W.O. JR., SASSA, S., BICKERS, D. KAPPAS, A.: (1978) Studies on porphyrin-heme biosynthesis in organotypic cultures of chick dorsal root ganglion. I. Observations on neuronal and nonneuronal elements. J. Neuropathol. Exp. Neurol. 37, 497-507.

WINKELMAN, J.: (1962) The distribution of tetraphenylporphinesulfonate in the tumorbearing rat. Cancer Res. 22. 589-596.
WINKELMAN, J.: (1967) Metabolic studies on the accumulation of tetraphenylporphinesulfonate in tumors. Experienta 23,949-950.

WINKELMAN, J.. HAYES, J.E.: (1963) Distribution of endogenous and parenterally administered porphyrin in viable and necrotic portions of a transplantable tumor. Nature 200. 903-904.

WINKELMAN, J., SLATER, G., GROSSMAN, J.: (1967) The concentration in tumor and other tissues of parenterally administered tritium- and ${ }^{14} \mathrm{C}$-labeled tetraphenylporphinesulfonate. Cancer Res, 27, 20602064.

WOCHNIK-DYJAS, D., NIEWIADOMSKA. M.. KOSTRZEWSKA. E.: (1978) Porphyric polyneuropathy and its pathogenesis in the light of electrophysiological investigations. J. Neurol. Sci. 35, 243-256. 